\title{
Foliar spraying of doses of boric acid in coriander (Coriandrum sativum L.)
}

\author{
Jéssica Rodrigues de Mello Duarte ${ }^{1}$, Scarlet de Aguiar Basílio ${ }^{1}$, Isabela Carolina Silva ${ }^{1}$, Elaine \\ Gleice Silva Moreira ${ }^{1}$, Adilson Pelá ${ }^{1}$
}

${ }^{1}$ Universidade Estadual de Goiás, Campus Ipameri, Ipameri, Goiás, Brasil. E-mail: jessicamello13@hotmail.com, scarletaguiar@yahoo.com.br, isabelac.silva@hotmail.com, elaine.moreira.230@gmail.com, adilson.pela@ueg.br

Received: 20/03/2019; Accepted: 18/12/2019.

\section{ABSTRACT}

Coriander (Coriandrum sativum) is a species highly appreciated in Brazilian cuisine and of high nutritional importance due to the presence of vitamins, calcium, and iron. Leafy vegetables are considered nutritionally demanding as their cycles are relatively short and the lack of any essential element affects their growth, yield and quality. This study aimed to evaluate the response of coriander plants (Coriandrum sativum L.) to foliar spraying of boron doses. The experiment was carried out in a greenhouse at The State University of Goiás, Campus Ipameri, in Ipameri-GO. The experimental design was completely randomized, with five treatments and four replications. The treatments consisted of five boron doses applied by foliar spray $(0,1.0,1.5,2.0$ and $3.0 \mathrm{~kg}$ ha-1) using boric acid (17\% of Boron) as the source. Fresh and dry matter of shoot and root and leaf boron contents were evaluated. Data were subjected to analysis of variance (F test) and the effect of boron doses were evaluated by regression analysis. The application of $3.0 \mathrm{~kg} \mathrm{ha}^{-1}$ of boron increases the boron content of coriander plants, and the fresh and dry matter of roots and shoots was not significantly increased.

Keywords: Fertilization, Micronutrients, Vegetable, Leafy.

\section{Doses de ácido bórico via foliar na cultura do coentro (Coriandrum sativum L.)}

\section{RESUMO}

O coentro é uma espécie bastante apreciada na culinária brasileira e de alta importância nutricional devido à presença de vitaminas, cálcio e ferro. As hortaliças folhosas são consideradas exigentes nutricionalmente, visto que seus ciclos são curtos e a falta de qualquer elemento essencial à planta afeta seu crescimento, produtividade e qualidade. O objetivo desse estudo foi analisar a resposta da cultura do coentro (Coriandrum sativum L.) a diferentes doses de boro via foliar. O experimento foi desenvolvido em casa de vegetação na Universidade Estadual de Goiás, Campus Ipameri, localizada no município de Ipameri-GO, e o delineamento experimental utilizado foi o inteiramente casualizado, com cinco tratamentos e quatro repetições. Os tratamentos foram cinco doses de boro (0; 1; 1,5; 2 e $\left.3 \mathrm{~kg} \mathrm{ha}^{-1}\right)$ na forma de ácido bórico (17\% de B), via foliar. Foram avaliadas a massa fresca e seca da parte aérea e da raiz e os teores de boro foliar. Os dados foram submetidos à análise de variância (teste $\mathrm{F}$ ) e o efeito das doses de boro, avaliados pela análise de regressão. A aplicação de $3 \mathrm{~kg} \mathrm{ha}^{-1}$ de boro aumenta o teor de boro nas plantas de coentro, já a massa seca e fresca das raízes e da parte aérea não foi incrementada significativamente.

Palavras-chave: Adubação, Micronutrientes, Hortaliça, Folhosas. 
Coriander (Coriandrum sativum) is a species highly appreciated in Brazilian cuisine and of high nutritional importance due to the presence of vitamins A, B1, B2, and $\mathrm{C}$, as well as calcium and iron. For its conventional grow, there is consolidated information, such as its vegetative cycle is approximately 50 days in summer and 70 days in winter, and its market size ranges from 25 to $30 \mathrm{~cm}$ in height (Luz et al., 2012).

They are usually grown in home gardens in small farms (Linhares et al., 2012). The national production of coriander seeds and the import volume are of high relevance, especially in the commercialization sector of the northeast region. Coriander is considered a vegetable of great value and commercial importance, with emphasis on exploitation to produce leafy vegetables. Leafy vegetables are considered nutritionally demanding as their cycles are relatively short and the lack of any essential element affects their growth, yield and quality (Daflon et al., 2014).

There are several studies on mineral nutrition in coriander culture, but there are still few studies related to micronutrients. Linhares et al. (2012) found that the hairy woodrose (Merremia aegyptia L.) as green manure was favorable to the agronomic performance of coriander crop and provided higher yield.

Boron acts as an enzyme regulator in the processes of membrane structure and function (solute inlet and outlet), carbohydrate synthesis and transport, protein synthesis, nitrogen fixation, photosynthesis, and growth, as well as providing disease resistance as it also participates in cell wall formation (Fernandes, 2006). It also improves flower fertilization, acting on cell differentiation, maturation, and division (Prado, 2008).

Species vary significantly in their responses to boron, and the interval between deficiency and toxicity is very narrow when compared to other essential nutrients. The definition of boron doses to be applied depends on several factors, including soil analysis, leaf analysis, plant species, crop rotation, climatic conditions, crop management and soil organic matter. (Lopes, 1998). Trani et al. (2015) emphasize the importance of fertilization according to soil and leaf analysis, aiming to meet the needs of the plant and ensure high yields.

Many legumes species, as well as various fruit and vegetables, are highly responsive to boron, and grain species are generally less responsive. Micronutrient deficiency generally slows plant growth, first affecting growth points and young leaves, which indicates that boron is not rapidly translocated in the plant (Lopes, 1998).

Daflon et al. (2014) found that treatments with boron omission in coriander plants reduced the dry matter of leaves, stems, and roots, and observed that younger leaves of coriander plants showed symptoms of wrinkled leaves, with the presence of chlorotic and whitish spots, making the apical meristem necrotic.

Due to the importance of borated fertilization in coriander leaf yield and quality, this study aimed to evaluate the response of coriander plants (Coriandrum sativum $\mathrm{L}$.) to foliar spraying of boron doses.

The experiment was carried out in a greenhouse at The State University of Goiás, Campus Ipameri, in Ipameri-GO (17 $43^{\circ} \mathrm{S}, 48^{\circ} 22^{\prime} \mathrm{W}$, and $800 \mathrm{~m}$ a.s.l.). The climate of the region is AW type according to the Köppen classification, with an average temperature of $21.9^{\circ} \mathrm{C}$ and relative air humidity ranging from $58 \%$ to $81 \%$. The annual rainfall is approximately $1447 \mathrm{~mm}$, concentrated from October to March. The soil is classified as Latossolo Vermelho-Amarelo and it is located within the Cerrado biome (Rubel and Kottek, 2010; Santos et al., 2013).

The completely randomized design was used, with five treatments and four replications. The treatments consisted of five boron doses applied by foliar spray ( 0 , $1.0,1.5,2.0$, and $\left.3.0 \mathrm{~kg} \mathrm{ha}^{-1}\right)$ using boric acid (17\% of Boron) as the source. Each plot consisted of three plastic pots filled with $5.0 \mathrm{dm}^{3}$ of soil, containing six plants per pot, totaling 20 plots, all of which were considered useful. Doses were applied three times with an interval of seven days between applications, maintaining the same volume of spray. The first application was made seven days after the transplanting of seedlings. For planting fertilization, $100 \mathrm{mg}$ of $\mathrm{N}$, $200 \mathrm{mg}$ of $\mathrm{P}_{2} \mathrm{O}_{5}$ and $200 \mathrm{mg}$ of $\mathrm{K}_{2} \mathrm{O}$ were applied using urea $(45 \% \mathrm{~N})$, triple superphosphate $\left(46 \% \mathrm{P}_{2} \mathrm{O}_{5}\right)$ and potassium chloride $\left(60 \% \mathrm{~K}_{2} \mathrm{O}\right)$ as sources, respectively.

The sowing was done in plastic pots, and the seedlings transplantation occurred when the plants were about 30 days old, in November 2018. Seedlings of cultivar Verdão were obtained from a commercial nursery. Weed control was carried out by hand weeding. The water supply was done once a day, according to the demand of the crop, with a watering can.

Harvesting was performed 25 days after transplantation. After harvest, the plants were sectioned into two parts (shoot and root) and immediately weighed on a precision scale $(0.01 \mathrm{~g})$ to obtain fresh matter of shoot and root. Dry matter of shoot and root were quantified after weighing the total fresh mass. Plants were placed in paper bags and left to dry in a forced air circulation oven at $70^{\circ} \mathrm{C}$ for 48 hours and then weighed on a precision scale $(0,01 \mathrm{~g})$. Data were noted and subsequently analyzed (Tavella et al., 2010).

Leaf boron contents were evaluated. After drying the material in a forced air circulation oven at $70^{\circ} \mathrm{C}$ for 48 hours, the material was ground in a Wiley type mill with a $1 \mathrm{~mm}$ mesh screen and placed in paper bags for analysis. The oven-dried digestion was performed, and the boron determined by spectrophotometry with 
azomethine-H, following the methods described by Malavolta et al. (1997). Data were subjected to analysis of variance (F test), and the effect of boron doses was evaluated by regression analysis. Statistical analyses were processed using the $\mathrm{R}$ statistical analysis program, version 3.5.1 (R Core Team, 2018).

The effects of boron doses on fresh and dry matter of shoot and root are shown in Table 1. The boron doses analyzed did not influence the fresh and dry matter of root and shoot of coriander plants. A similar result was obtained by Silva et al. (2014), who evaluated the application of boron doses at different phenological stages in the cabbage crop and did not observe influence on fresh and dry matter of leaves.

For the shoot and root dry matter variables, it was not possible to identify a significant influence of the applied boron doses. About the effects of boron doses on shoot dry matter, there was a variation of $1.029 \mathrm{~g}$ plant $^{-1}$ at dose $0 \mathrm{~kg} \mathrm{ha}^{-1}$ and $1.479 \mathrm{~g} \mathrm{plant}^{-1}$ at $3 \mathrm{~kg} \mathrm{ha}^{-1}$ dose of boron. Root dry matter ranged from 0.354 to $0.548 \mathrm{~g} \mathrm{plant}^{-1}$. Therefore, there was no increase in dry matter of coriander according to the increase of boron doses. This result is similar to that found by Zanão Júnior et al. (2014), who observed that root dry matter was not influenced by the application of different doses of boron.

Salvador et al. (2003), evaluating boron doses ( 0 , $0.125,0.250,0.500,1.000,1.500$, and $\left.3.000 \mathrm{mg} \mathrm{L}^{-1}\right)$ in guava, did not find a statistical difference in the root dry matter, and the best treatment was $0.25 \mathrm{mg} \mathrm{L}^{-1}$ of boron.

The foliar application of boron in coriander plants influenced the average values of boron content in roots and shoots (Figures 1 and 2). The lowest average boron content was observed in the control treatment $\left(0 \mathrm{~kg} \mathrm{ha}^{-1}\right.$ boron). The increase in boron content occurred linearly with increasing boron doses. The dose of $3 \mathrm{~kg} \mathrm{ha}^{-1}$ of boron had the best results when compared to the other doses, where it was possible to verify the highest average boron content in the shoot (Figure 1) and roots (Figure 2). Despite being considered a high dose for foliar application, no phytotoxicity was observed, maybe because the boron doses were divided into four applications. The increase in boron contents in the roots also suggests that part of the element may have been absorbed via soil, as the nutrient is considered immobile in the plant. Silva et al. (2012) found similar results for cabbage plants, where the application of boron doses positively influenced leaf boron content.

Table 1. Effect of boron doses on shoot fresh matter (SFM), root fresh matter (RFM), shoot dry matter (SDM), root dry matter (RDM) of coriander plants. Ipameri-GO, 2019.

\begin{tabular}{ccccc}
\hline $\begin{array}{c}\text { DOSES } \\
\mathrm{kg} \mathrm{ha}^{-1}\end{array}$ & SFM & RFM & SDM & RDM \\
\hline 0.0 & 1.964 & 0.927 & 1.029 & 0.445 \\
1.0 & 2.541 & 1.242 & 1.254 & 0.548 \\
1.5 & 1.771 & 0.708 & 1.098 & 0.354 \\
2.0 & 2.328 & 0.946 & 1.056 & 0.377 \\
3.0 & 2.272 & 0.956 & 1.479 & 0.533 \\
\hline F-test & $0.602^{\text {ns }}$ & $0.518^{\text {ns }}$ & $1.153^{\text {ns }}$ & $0.708^{\text {ns }}$ \\
\hline CV $(\%)$ & 31.4 & 47.81 & 25.5 & 40.1 \\
\hline
\end{tabular}

ns: not significant at 5\%.

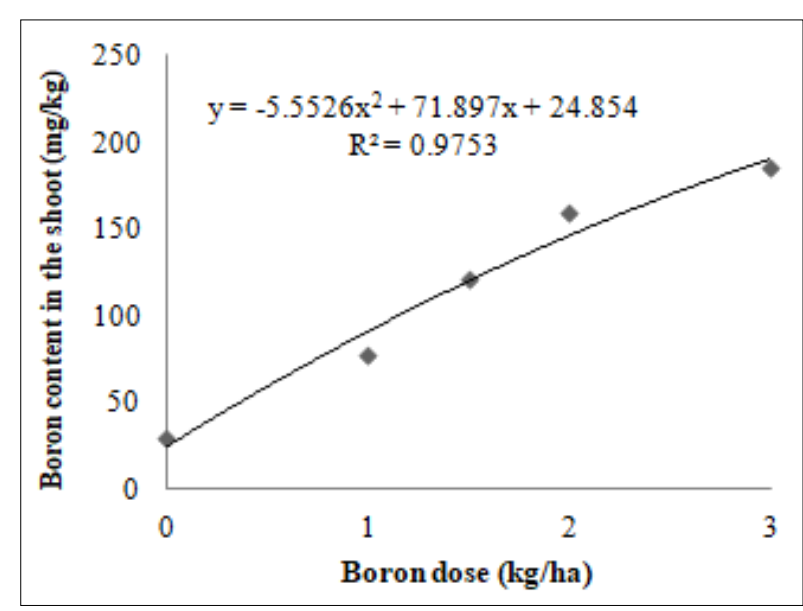

Figure 1. Boron content $\left(\mathrm{mg} \mathrm{kg}^{-1}\right)$ in the shoot of coriander plants. Ipameri-GO, 2019.

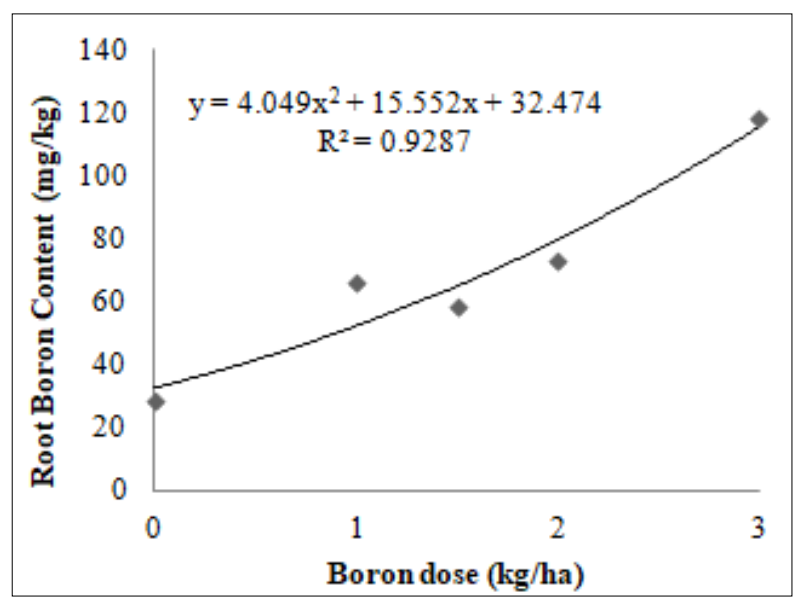

Figure 2. Boron content $\left(\mathrm{mg} \mathrm{kg}^{-1}\right)$ in roots of coriander plants. Ipameri-GO, 2019. 
In the radish culture, Mesquita et al. (2011) found similar results to those found in this study. They found that increasing boron doses $\left(0,1,2,3\right.$, and $\left.5 \mathrm{mg} \mathrm{dm}^{-3}\right)$ did not influence the fresh matter of the shoot but influenced the leaf boron content. Boron content concerning different doses is also responsive in onion leaves, as observed by Kurtz and Ernani (2010).

There are few studies on boron fertilization in coriander plants. It is noteworthy that crop yield is dependent on soil, climatic conditions, cultivar, soil management, crop management, and, mainly, fertilization. Thus, the correct and proper maintenance of the crop is of fundamental importance to achieve excellent productivity, resulting in economic return.

Leaf fertilization with $3.0 \mathrm{~kg} \mathrm{ha}^{-1}$ of boron increased the boron content in coriander plants but did not change the fresh and dry matter of root and shoot.

\section{Bibliographic References}

Daflon, D.G., Freitas, M.S.M., Carvalho, A.J.C., Monnerat, P.H., Prins, C.L., 2014. Sintomas visuais de deficiência de macronutrientes e boro em coentro. Horticultura Brasileira, 32(1), 28-34.

Fernandes, M.S., 2006. Nutrição Mineral de Plantas, primeira ed. Sociedade Brasileira de Ciência do Solo, Viçosa.

Kurtz, C., Ernani, P.R., 2010. Produtividade de cebola influenciada pela aplicação de micronutrientes. Revista Brasileira de Ciência do Solo, 34(1), 133-142.

Linhares, P.C.F., Pereira, M.F.S., Assis, J.P., Bezerra, A.K.H., 2012. Quantidades e tempos de decomposição da jitirana no desempenho agronômico do coentro. Ciência Rural, 42(2), 243-248.

Lopes, A.S., 1998. Manual Internacional de Fertilidade do Solo, segunda ed. Potafos, Piracicaba.

Luz, J.M.Q., Andrade, L.V., Dias, F.F., Silva, M.A.D., Haber, L.L., Oliveira, R.C., 2012. Produção hidropônica de coentro e salsa crespa sob concentrações de solução nutritiva e posições das plantas nos perfis hidropônicos. Bioscience Journal, 28(4), 589-597.

Malavolta, E., Vitti, C.G., Oliveira, S.A., 1997. Avaliação do estudo nutricional das plantas: princípios e aplicações, segunda ed. Potafos, Piracicaba.
Mesquita, G.M., Costa, S.M., Buso, W.H.D., Silva, S.D.D., 2011. Produção de rabanete cultivado sob diferentes doses de boro com presença e ausência de calagem. Global Science and Technology, 4(2), 18-26.

Prado, R.M., 2008. Nutrição de plantas, primeira ed. Unesp, São Paulo.

R Core Team, 2018. R: A Language and Environment for Statistical Computing. Vienna, Austria: R Foundation for Statistical Computing. https://www.r-project.org/ (Accessed December 10, 2018).

Rubel, F., Kottek, M., 2010. Observed and projected climate shifts 1901-2100 depicted by world maps of the KöppenGeiger climate classification. Meteorologische Zeitschrift, 19(2), 135-141.

Salvador, J.O., Moreira, A., Malavolta, E., Cabral, C.P., 2003. Influência do boro e do manganês no crescimento e na composição mineral de mudas de goiabeira. Ciência e agrotecnologia, 27(2), 325-331.

Santos, H.G., Jacomine, P.K.T., Anjos, L.H.C., Oliveira, V.A., Lumbreras, J.F., Coelho, M.R., Almeida, J.A., Cunha, T.J.F., Oliveira, J.B., 2013. Sistema brasileiro de classificação de solos, terceira ed. Embrapa, Brasília.

Silva, K.S., Santos, E.C.M., Benett, C.G.S., Laranjeira, L.T., Eberhardt Neto, E., Costa, E., 2012. Produtividade e desenvolvimento de cultivares de repolho em função de doses de boro. Horticultura Brasileira, 30(3), 520-525.

Silva, L.M., Basílio S.A., Silva Júnior, R.L., Nascimento, M.V., Benett, C.G.S., Benett, K.S.S., 2014. Aplicação de ácido bórico sobre as características produtivas do repolho em diferentes épocas. Revista de Agricultura Neotropical, 1(2), 26-34.

Tavella, L.B., Galvão, R.O., Ferreira, R.L.F., Araújo Neto, S.E., Negreiros, J.R.S., 2010. Cultivo orgânico de coentro em plantio direto utilizando cobertura viva e morta adubado com composto. Revista Ciência Agronômica, 41(4), 614-618.

Trani, P.E., Purquério, L.F.V., Figueiredo, G.J.B., Tivelli, S.W., Blat, S.F., 2015. Calagem e adubação da alface, almeirão, agrião d'água, chicória, coentro, espinafre e rúcula. Revista Attalea Agronegócios, (99), 44-47.

Zanão Júnior, L.A., Carvalho-Zanão, M.P., Fontes, R.L.F., Grossi, J.A.S., 2014. Produção e qualidade de rosas em razão de doses de boro aplicadas no substrato. Revista Brasileira de Ciência do Solo, 38(2), 524-531. 